\title{
Application electronic marketing to help marketing leading products village
}

\author{
Yudo Devianto * and Saruni Dwiasnati \\ Faculty of Computer Science, Universitas Mercu Buana, Jakarta, Indonesia.
}

GSC Advanced Engineering and Technology, 2021, 01(01), 065-074

Publication history: Received on 19 April 2021; revised on 21 May 2021; accepted on 23 May 2021

Article DOI: https://doi.org/10.30574/gscaet.2021.1.1.0030

\begin{abstract}
The research we will do is follow-up research from previous research in 2019, namely: "Application of E-Business in Village Government (Study on Marketing of Village Leading Products)", in previous studies it has been stated that applying the concept of E-Business to help market superior products village. In the current research, we will try to make a model or design of an application that can help in marketing the village's superior products. This type of research we use is applied research (Applied Research) because the results of the research can be directly used/applied to solve the problems faced and the implementation of e-business design using the information systems development (ISD) method. The traditional systems development life cycle (SDLC) method provides structured and formal steps. However, this method needs to be changed to adapt to the conditions of information technology and the increasingly complex needs and requires great flexibility and responsiveness. Various modern methods are available for the development of complex systems or those that are desired to be quickly realized, for example, prototyping, joint application design, object-oriented development, and component-based development. This E-Marketing application was created to be able to help promote and market products that are superior to the village. The design of this application is made to make it easier for village communities to promote and market their village's superior products. With this E-Marketing application, information on superior village products can be seen by the wider community. The result of this research is a prototype of the E-Marketing application that can be applied as a solution to promote and market the village's superior products.
\end{abstract}

Keywords: e-business; Superior village products; Market the product

\section{Introduction}

The research we will do is follow-up research from previous research in 2019, namely: "Application of E-Business in Village Government (Study of Marketing of Village Leading Products)"[10, 11, 12, 13, 14, 15, 16, 17], in previous research, it has been stated that applying the concept of E-Business to help market superior village products [3].

The previous research only discussed the application of the right E-Business concept to assist in marketing superior village products $[1,2,3,4,5]$.

Previous research used village superior product data from 2 villages, it can be seen in the following table.

\footnotetext{
${ }^{*}$ Corresponding author: Yudo Devianto; Email:yudo.devianto@mercubuana.ac.id

Faculty of Computer Science, Universitas Mercu Buana, Jakarta, Indonesia. 
Table 1 Village Featured Products.

\begin{tabular}{|c|c|c|c|c|c|}
\hline Province Name & : & East Nusa Tenggara & Province Name & : & $\begin{array}{ll}\text { East } & \text { Nusa } \\
\text { Tenggara } & \end{array}$ \\
\hline Village Name & : & Kailesa & Village Name & : & Purnama \\
\hline $\begin{array}{l}\text { Village } \quad \text { Leader } \\
\text { Name }\end{array}$ & : & Jefri Nase Sailana & Village Leader Name & : & Melkisedek Lukuaka \\
\hline Village Area & : & $23,30 \mathrm{Km}^{2}$ & Village Area & : & $36,23 \mathrm{Km}^{2}$ \\
\hline $\begin{array}{l}\text { Number of Family } \\
\text { Heads }\end{array}$ & $:$ & 248 & $\begin{array}{l}\text { Number of Family } \\
\text { Heads }\end{array}$ & $:$ & 288 \\
\hline $\begin{array}{ll}\text { Village } & \text { Featured } \\
\text { Products } & \end{array}$ & : & $\begin{array}{l}\text { Candlenut, Walnuts, } \\
\text { Tamarind }\end{array}$ & $\begin{array}{ll}\text { Village } & \text { Featured } \\
\text { Products } & \end{array}$ & $:$ & $\begin{array}{l}\text { Fish, Tamarind, } \\
\text { Woven }\end{array}$ \\
\hline
\end{tabular}

In the current research, we will try to make a model/design of an application that can later help market the superior products of the village. The things that have existed in previous research can be seen in the following table.

Table 2 Previous research results.

\begin{tabular}{|l|l|}
\hline No & Information \\
\hline 1 & $\begin{array}{l}\text { E-Marketing applications can be made referring to the concept of implementing B2B and } \\
\text { B2G E-Business. }\end{array}$ \\
\hline 2 & $\begin{array}{l}\text { This application is here to make it easier for village communities to market and introduce } \\
\text { their village's superior products widely. }\end{array}$ \\
\hline 3 & $\begin{array}{l}\text { By using the E-Marketing application, the superior products of the village will be widely } \\
\text { recognized by the community. }\end{array}$ \\
\hline
\end{tabular}

Based on table No.2, the application design to be made refers to the B2B E-Business concept.

\section{Objectives And Benefits}

The purpose of this study is to continue previous research that has determined the E-Business concept that will be applied to the E-Marketing application, namely designing an application that will be able to assist in promoting and marketing superior village products.

The benefit of this research is that the results of the model or design of this application can be made and implemented into an application that can help to promote and market superior village products. The model or design of this application can also be used by villages that have the same problems.

\section{Research Methods}

The type of research we use is applied research (Applied Research) because the results of the research can be directly used/applied to solve the problems faced and the implementation of e-business design using the information systems development (ISD) method.

The traditional systems development life cycle (SDLC) method provides structured and formal steps. However, this method needs to be changed to adapt to the conditions of information technology and the increasingly complex needs and requires great flexibility and responsiveness. Various modern methods are available for the development of complex systems or those that are desired to be quickly realized, for example, prototyping, joint application design, object-oriented development, and component-based development [6]. 
For e-business development in this cluster, a combination of the advantages of structured and formal SDLC, as well as prototyping and component-based development will be applied.

In this research, a Model or Design of a Promotion and Marketing Application Design for the Village's Leading Products will be made.

The data collection method used in this research is $[7,8]$.

Observation method: Observation or direct observation of the research object. The observation technique is carried out with structured observation by preparing a list of data requirements and data sources.

Method of literature study: The method of collecting data obtained by studying, researching, and reading books, information from the internet, journals, theses, related to e-business and villages.

\section{Results and discussion}

System design determines how the system will meet these objectives, in this case: hardware, software, network infrastructure; user interface, forms, and reports, as well as special programs, databases, and files that will be required. System design is an advanced stage of system analysis [9] where the system design describes the system to be built before coding is carried out in a programming language. In designing a system it cannot be separated from the results of the analysis. The system design in this study can be seen in Figure 1.

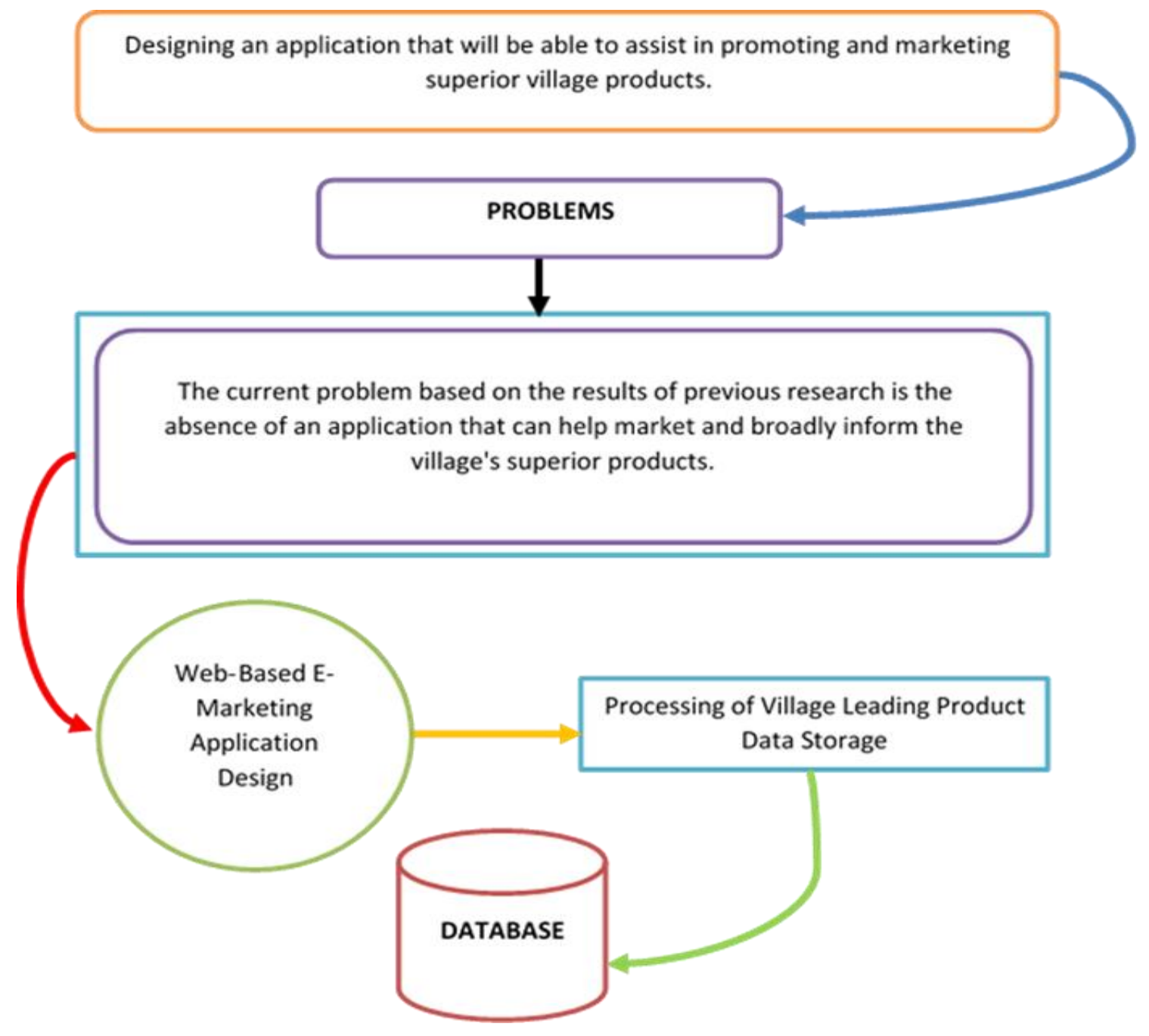

Figure 1 System Design Concept 
From the system design concept in general, it can be explained as follows, in conducting this research a web-based EMarketing application design will be created, which is expected to be implemented in solving existing problems, namely the absence of an application that can help market and widely inform superior products village.

\subsection{Deployment Diagram}

A deployment diagram is a diagram that shows and explains the architecture of a relationship between hardware and software visually from the application [18]. The network architecture that is formed is a collection of nodes in the form of hardware and software that configure runtime software components with processors and other equipment. Deployment describes the details of how the components are deployed in the system infrastructure, where the components will be located (on a machine, server, or pc), how the network capabilities are at that location, server specifications, and other physical things. A node is a server, workstation, or other hardware used to deploy components in a real environment. The relationship between nodes (eg TCP / IP) and requirements can also be defined in this diagram. The following is the deployment diagram of the E-Marketing application design that will be made.

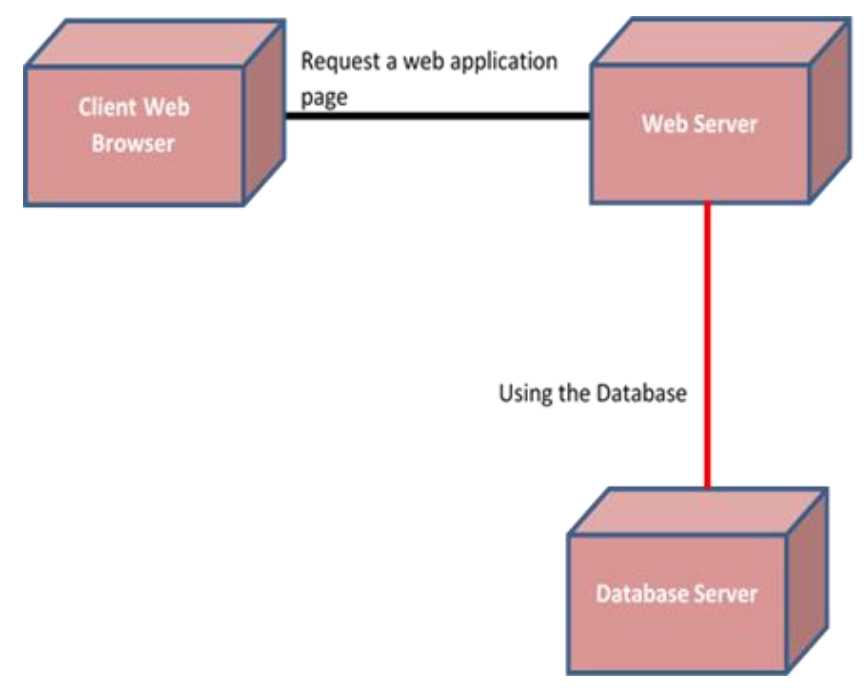

Figure 2 Deployment of E-Marketing Application Design Diagram

From the deployment diagram image, it can be explained as follows: 1. Client Web Browser, the location where the EMarketing application will be run, when the application is run, the E-Marketing application page will appear on the Web Server. 2. The Web Server location where the E-Marketing application is located, when the application page appears in the Client Web Browser, the application also uses a database that is on the Database Server. 3. Database Server location where the database required by the E-Marketing application is located.

\subsection{Business Process Design}

A business process is a process that describes the workflow or work mechanism carried out by the unit or related parties, the documents or data used or generated [19].

From the picture of the business process above, it can be explained as follows, it can be seen in business processes, the E-Marketing application is managed by users and administrators, data is entered to be processed into valid information so that the wider community can find out this information so that business processes can run as expected support for web server technology and good data storage. 


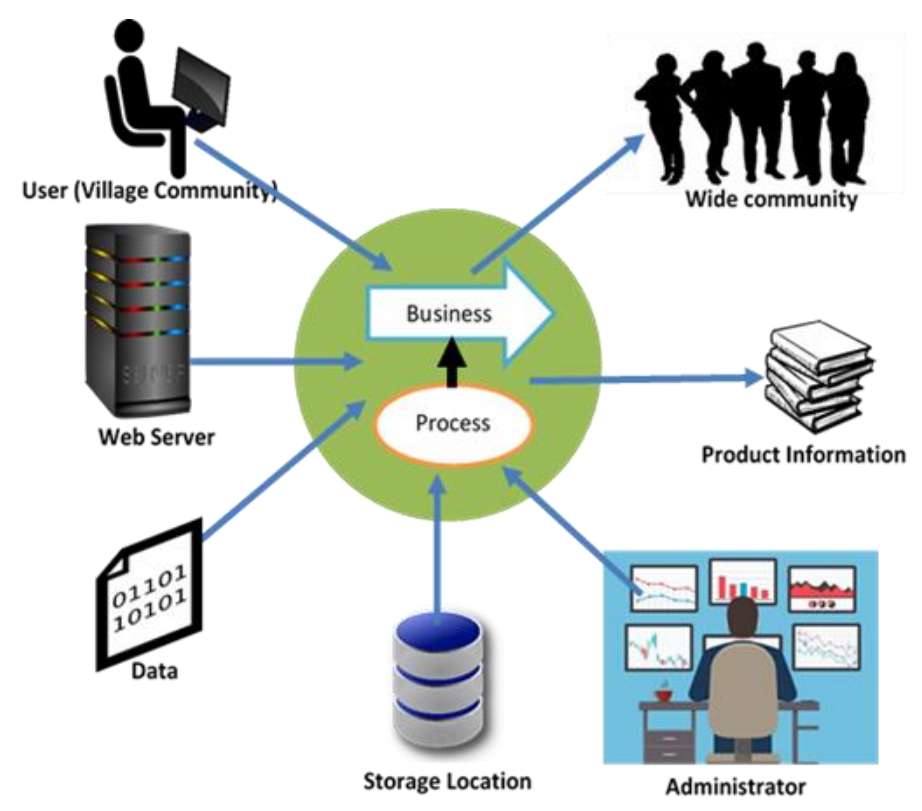

Figure 3 E-Marketing Application Business Process Design

\subsection{Architectural Infrastructure Design}

At this stage the design of the web-based E-Marketing application will be explained, which later the application will be used to process data containing information on superior village products, by this application the processed information will be used to inform and market superior products the village to the wider community.

The infrastructure design of this E-Marketing Application architecture is as follows:

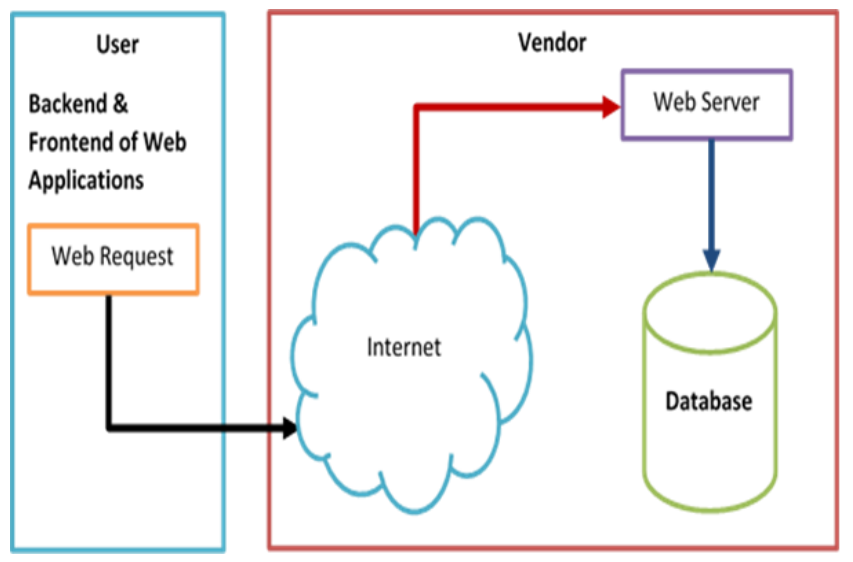

Figure 4 E-Marketing Application Design Architecture Infrastructure Design

In the architectural infrastructure design drawing, it can be explained as follows, the location of the User (backend and frontend of the web application),

- The backend of the web application is managed by an administrator.

- The backend web application also manages product data that is processed by user and administrator authorities.

- The backend of the web application also manages the authorization of the user who has the right to access the backend of the application.

- Frontend web application will display product data information that has been processed on the backend.

- With the frontend of the web application, information on superior village product data can be seen by people who are looking for or needing these products. 
The vendor location contains the webserver where the web application is stored along with the database, through the front and backend of the web application, to access the web application using the internet network.

\subsection{Interface Construction}

At this stage, an interface construction for the E-Marketing application will be made.

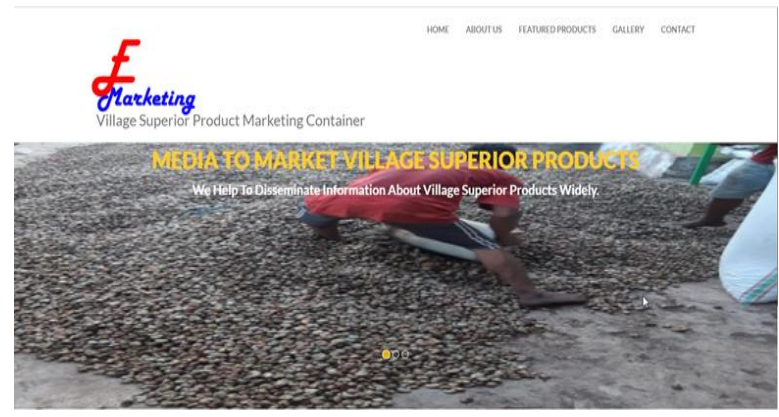

Figure 5 E-Marketing Application Frontend

In the image of the E-Marketing application frontend interface, there are several menus, which are shown in the following table:

Table 3 E-Marketing Application Frontend Menu.

\begin{tabular}{|l|l|}
\hline Menu & Information \\
\hline Home & $\begin{array}{l}\text { Contains picture slides of the village's superior products that are in the E- } \\
\text { Marketing application. }\end{array}$ \\
\hline About Us & Contains information about the E-Marketing application. \\
\hline Featured product & $\begin{array}{l}\text { Contains information about the superior products of the village, and } \\
\text { information on the villages that produce these products. }\end{array}$ \\
\hline Gallery & $\begin{array}{l}\text { Contains pictures or photographs related to the superior products of the } \\
\text { village, for example, harvesting activities, photos of product manufacturing } \\
\text { activities. }\end{array}$ \\
\hline Contact & Contains administrator information for the E-Marketing application. \\
\hline
\end{tabular}

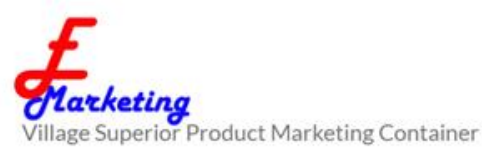

HOME ABOUTUS FEATUREDPRODUCTS GALIFYY CONTACT

PROVINCE NAME
VILLAGE NAME
NAME OF VILLAGE LEADER
VILLAGE AREA
NUMBER OF FAMILIES

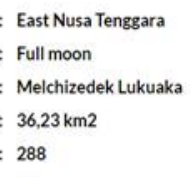

Figure 6 Frontend Menu for Featured Products of Purnama Village 

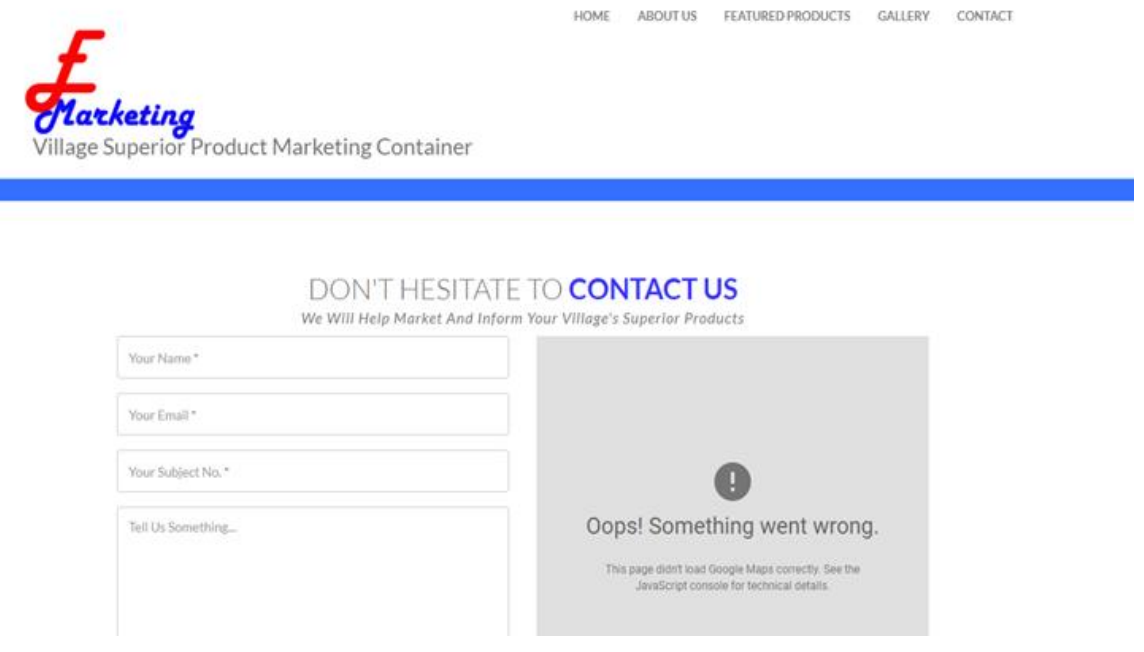

Figure 7 Frontend Menu Contacts

The data contained in the E-Marketing application uses data from two villages, namely Purnama Village and Kailesa Village, I got this data from academic colleagues from Tribuana Kalabahi University, Alor, East Nusa Tenggara. The data is entered using the E-Marketing application backend, as shown in the following figure.

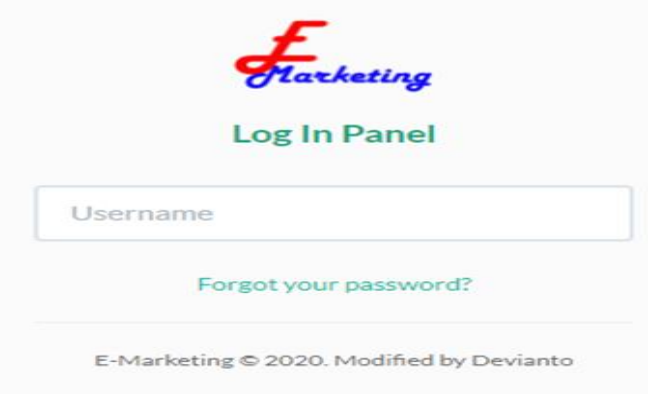

Figure 8 Menu Login Backend

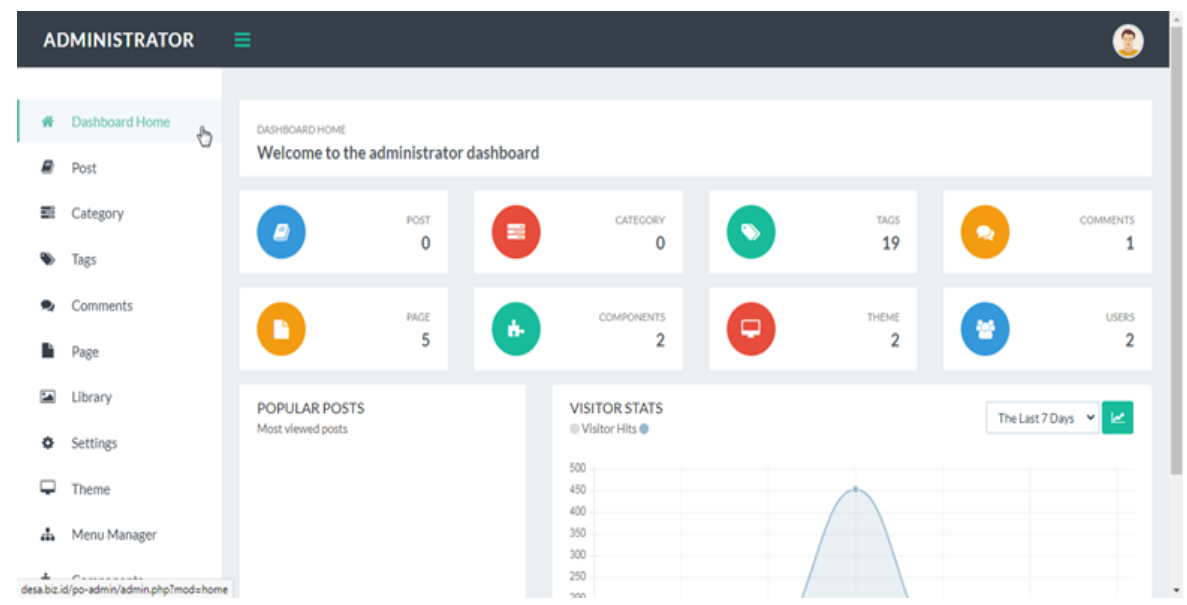

Figure 9 E-Marketing Application Backend Dashboard

In the construction drawing of the E-Marketing application backend dashboard interface, you can see several menus that will be used to enter data that will be displayed on the frontend, the menus used can be seen in the following table: 
Table 4 E-Marketing Application Backend Menu.

\begin{tabular}{|l|l|}
\hline Menu & Information \\
\hline Page & $\begin{array}{l}\text { In this menu, the superior product data is entered and other data and the data will appear } \\
\text { on the E-Marketing application frontend. }\end{array}$ \\
\hline Settings & This menu is used to configure the E-Marketing application. \\
\hline Theme & This menu is used to set the frontend template to be used. \\
\hline Manager & $\begin{array}{l}\text { This menu is used to adjust the position of the menu that appears on the frontend and } \\
\text { backend of the E-Marketing application. }\end{array}$ \\
\hline Component & $\begin{array}{l}\text { In this menu set the gallery and contact menu on the frontend of the E-Marketing } \\
\text { application. }\end{array}$ \\
\hline User & In this menu, authorization for E-Marketing application backend users is set. \\
\hline
\end{tabular}
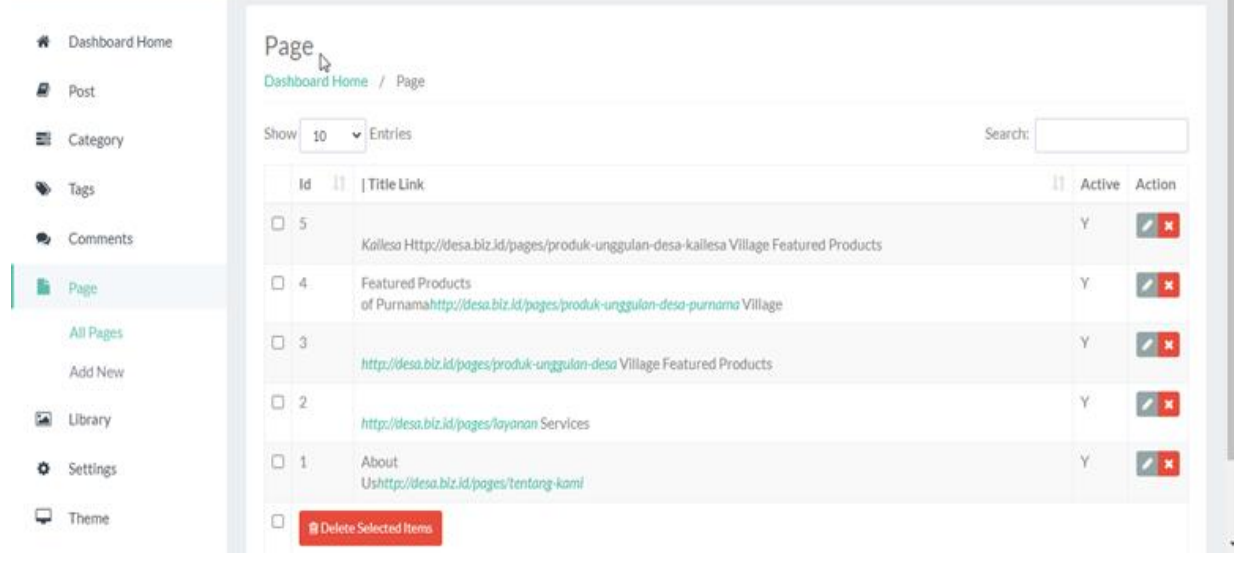

Figure 10 E-Marketing Application Backend Page Menu

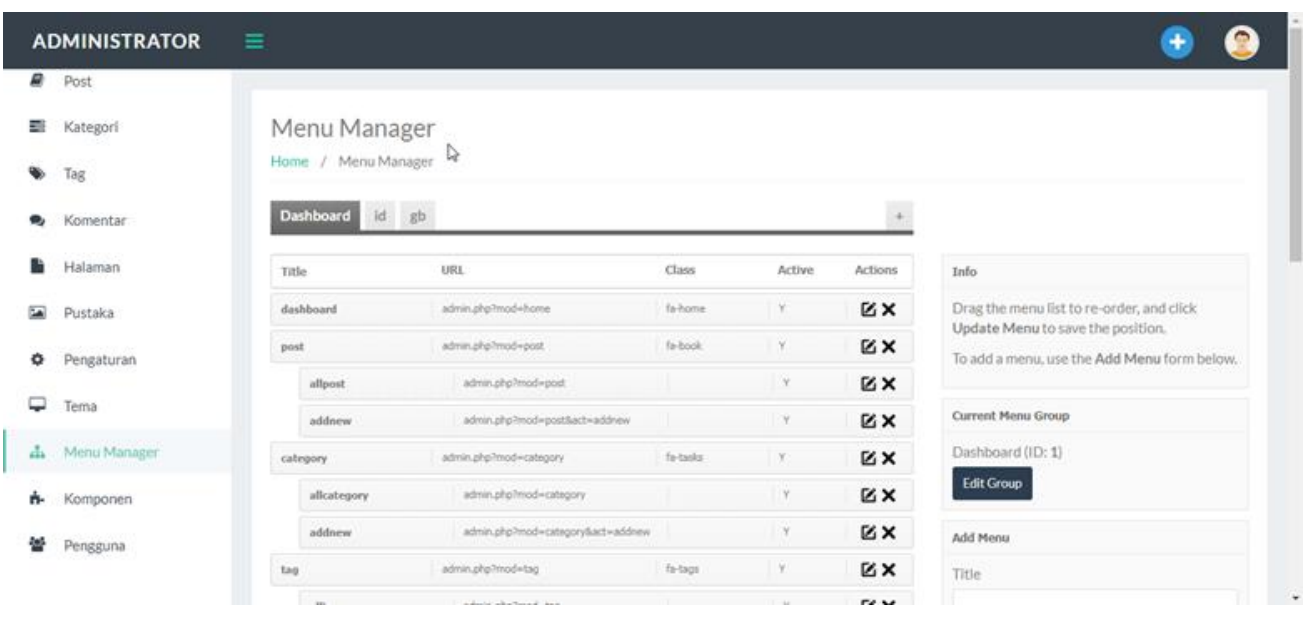

Figure 11 E-Marketing Application Backend Manager Menu 


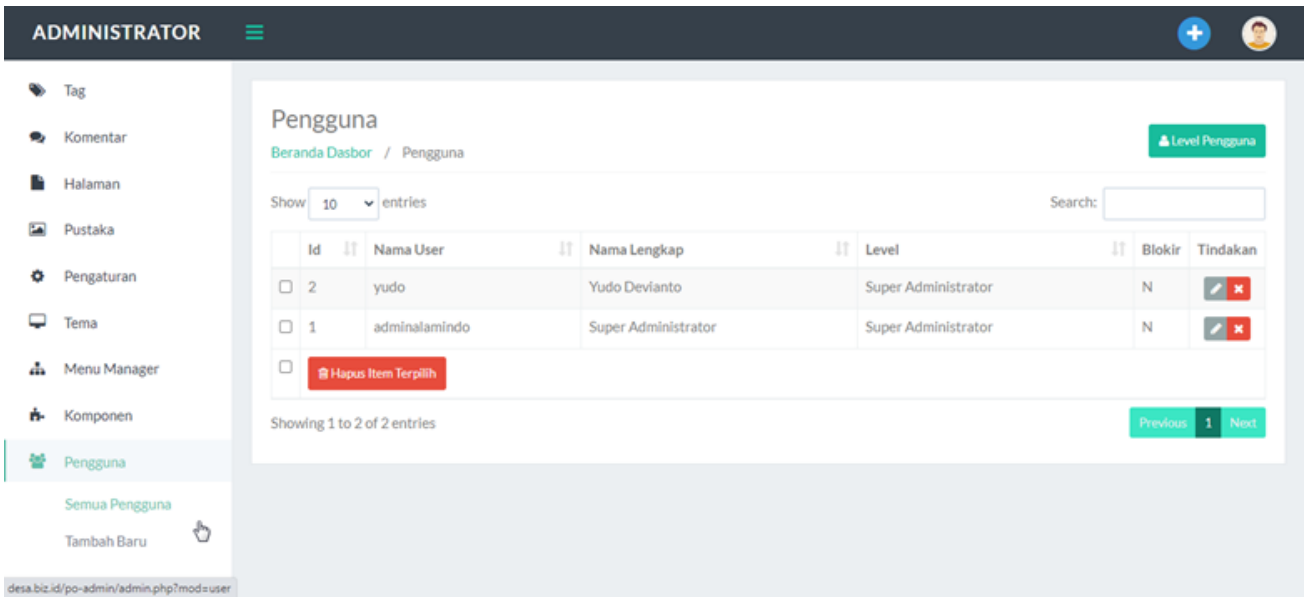

Figure 12 E-Marketing Application Backend User Menu

The design of this E-Marketing application is made to be able to help promote and market products that are superior to the village.

\section{Conclusion}

Based on the discussion of the research results that have been discussed in the previous chapter, in this research the Design of E-Marketing Applications to Help Marketing the Village's Superior Products the following conclusions and suggestions can be drawn: 1 . The design of this application was made to facilitate rural communities in promoting and marketing superior products to their village. 2. With this E-Marketing application, information on superior village products can be seen by the wider community. 3. The result of this research is a prototype of the E-Marketing application that can be applied as a solution to promote and market the village's superior products. 4. The suggestion that we can convey is that this application can be developed and improved for the better by utilizing renewable technologies in the field of information technology.

\section{Compliance with ethical standards}

\section{Acknowledgments}

Praise and gratitude to God Almighty for all His mercy and grace so that this internal research has been completed. Not to forget, we would like to thank our family, the Universitas Mercu Buana, the Faculty Of Computer Science, and especially the PUSLIT Universitas Mercu Buana who have provided research funding support. The theme chosen in this internal research activity is "Designing E-Marketing Applications to Help Marketing Superior Village Products". The author realizes that this report is far from perfect, therefore criticism and constructive suggestions are expected to be better. Hopefully, this report can be of benefit to readers. Thank you. No SPK: 02-5/485/B-SPK/II/2021.

\section{Disclosure of conflict of interest}

The authors declares that there is no conflict of interest in their research study.

\section{References}

[1] Undang-undang Republik Indonesia Nomor 6 Tahun 2014 Tentang Desa. 2014.

[2] Yani A. Pengaruh E-Business atas Proses dalam Organisasi Bisnis. 2017; (1): 16-21.

[3] Devianto Y, Dwiasnati S. Electronic Business Concept In Marketing Of Village Leading Products. 2020; 4(3): 172181.

[4] Devianto Y. Sistem Informasi Indeks Kepuasan Masyarakat Dengan Metode Perbandingan Eksponensial (Mpe) Dan Skala Ordinal Pada Unit Pelayanan Masyarakat", Jurnal Ilmiah FIFO, Universitas Mercu Buana. 2017; 9(1): 31-40. 
[5] Devianto Y, Dwiasnati S. Aplikasi Pengambilan Keputusan Indeks Kepuasan Masyarakat Dengan Metode Perbandingan Eksponensial (MPE) Pada Unit Pelayanan Masyarakat Dengan Alat Microcontroller Sebagai Alat Bantu Survey, Jurnal Ilmiah FIFO, Universitas Mercu Buana. 2018; 10(1): 13-21.

[6] Sugiyono. Metode Penelitian Kuantitatif, Kualitatif", dan R\&D. Bandung. Alfabeta. 2012.

[7] Team Penulis. Rencana Induk Penelitian UMB 2020-2025”, Universitas Mercu Buana. 2020.

[8] Anastasia AN, Handriani I. Aplikasi Sistem Order Jasa Graphic Designer Berbasis Web Pada PT. Decorner, Jurnal Ilmiah FIFO. 2018; 10(1): 87.

[9] Sahara R, Prastiawan H, Rizal D. Rancang Bangun Sistem Informasi Mylibrary Telkomsel Berbasis Website (Studi Kasus: PT. Telekomunikasi Selular), Jurnal Format. 2017; 6(1): 106-118.

[10] Labanauskaitė D, Fiore M, Stašys R. Use of E-marketing tools as communication management in the tourism industry. Tourism Management Perspectives. 2020; 34: 100652.

[11] Winarso W. e-Marketing: Business in Developing SMEs in Indonesia, International Journal of Psychosocial Rehabilitation. 2020; 24(10): 1931-1937.

[12] Firmansyah MA. Pengantar E-Marketing, Penerbit Qiara Media. 2020.

[13] Kasambu N, Sritharan R. A STUDY ON PROBLEMS AND PROSPECTS OF E-MARKETING. Studies in Indian Place Names. 2020; 40(3): 3447-3456.

[14] Al-Weshah G. E-marketing practices from Jordanian tourism agencies perspectives: a qualitative evidence. In Destination Management and Marketing: Breakthroughs in Research and Practice. 2020; 1170-1187.

[15] Irmal I, Gustiarani E, Sunarsi D. Pengaruh E-Marketing dan E-CRM terhadap E-Loyalty Pengunjung Situs Websitev www.Cangkirbogor.Com, Jurnal Ekonomi Efektif. 2020; 2(2).

[16] Erlangga E, Anggraini MH, Ariani F, Aprilinda Y. Aplikasi E-Marketing Panglong Kayu Menggunakan Metode Colaborative Filtering, Explore: Jurnal Sistem informasi dan telematika (Telekomunikasi, Multimedia dan Informatika). 2020; 11(1): 57-66.

[17] Awali H. Urgensi Pemanfaatan E-Marketing Pada Keberlangsungan UMKM di Kota Pekalongan di Tengah Dampak Covid-19, Balanca: Jurnal Ekonomi Dan Bisnis Islam. 2020; 2(1): 1-14.

[18] Wildan B, Sari AP, Nasution R. SISTEM INFORMASI MANEJEMEN SURAT BERBASIS WEB PADA PT. CLIPAN FINANCE INDONESIA, TBK, Hexagon Jurnal Teknik dan Sains. 2021; 2(1): 85-90.

[19] Wulandari N, Aribowo E. Analisis Dan Perancangan Proses Bisnis Dan Basis Data Untuk SIM (Sistem Informasi Manajemen) LSP AD, Jurnal Sarjana Teknik Informatika e-ISSN. 2019; 2338: 5197. 